\title{
PENGETAHUAN DAN PERILAKU SISWA TENTANG PENCEGAHAN COVID-19 DI SDIT RABBANI KOTA BENGKULU
}

\section{STUDENT KNOWLEDGE AND BEHAVIOR ABOUT COVID-19 PREVENTION IN SDIT RABBANI, BENGKULU CITY}

\author{
Oleh: \\ Veby Fransisca Rozi ${ }^{1}$, Susi Eryani ${ }^{2}$ \\ 1,2Program Studi Kesehatan Masyarakat STIKes Bhakti Husada Bengkulu \\ Email: vebybengkulu@gmail.com
}

\begin{abstract}
Background: Covid-19 is a new type of virus that has never been previously identified in humans. Bengkulu Province is included in the Covid-19 Red Zone with the number of cases as of October 2020 as many as 995 cases. In Bengkulu City as of October 26, 2020, Covid-19 cases totaled 567 cases. School age is an age that is quite vulnerable to being affected by Covid-19 because it really needs knowledge about preventing Covid-19. Objectives: To determine the frequency distribution of students' knowledge and behavior about Covid-19 prevention at SDIT Rabbani Bengkulu City. Methods: The type of research used is a cross sectional design. The population of this study were all students of SDIT Rabbani Bengkulu City, while the number of samples was 86 students. Data were analyzed univariately using SPSS. Results: Most students (72.1\%) know about the use of masks, most students (52.3\%) know about washing hands using soap, a few students (44.2\%) know about keeping a distance of 1 meter, some Most of the students (57\%) behaved well in using masks, a few students (39.5\%) behaved well in washing their hands with soap and a small number of students (31.4\%) behaved well in maintaining a distance of 1 meter.
\end{abstract}

Keywords: Knowledge, Behavior, Covid-19

\begin{abstract}
ABSTRAK
Latar Belakang: Covid-19 adalah virus jenis baru yang belum pernah diidentifikasi sebelumnya pada manusia. Provinsi Bengkulu termasuk dalam Zona Merah Covid-19 dengan jumlah kasus sampai dengan bulan Oktober 2020 sebanyak 995 kasus. Di Kota Bengkulu sampai dengan tanggal 26 Oktober 2020, kasus Covid-19 berjumlah 567 kasus. Usia sekolah merupakan usia yang cukup rentan terdampak Covid19 karena sangat perlu pengetahuan mengenai pencegahan Covid-19. Tujuan Penelitian: Untuk mengetahui distribusi frekuensi pengetahuan dan perilaku siswa tentang pencegahan Covid-19 di SDIT Rabbani Kota Bengkulu. Metode Penelitian: Jenis penelitian yang digunakan adalah desain cross sectional. Populasi penelitian ini adalah seluruh siswa SDIT Rabbani Kota Bengkulu, adapun jumlah sampel yaitu 86 siswa. Data dianalisis secara univariat menggunakan SPSS. Hasil Penelitian: Sebagian besar siswa $(72,1 \%)$ mengetahui tentang penggunaan masker, sebagian besar siswa $(52,3 \%)$ mengatahui tentang mencuci tangan menggunaan sabun, sebagian kecil siswa $(44,2 \%)$ mengetahui tentang menjaga jarak 1 meter, sebagian besar siswa (57\%) berperilaku baik dalam menggunakan masker, sebagian kecil siswa $(39,5 \%)$ berperilaku baik dalam mencuci tangan menggunakan sabun dan sebagian kecil siswa $(31,4 \%)$ berperilaku baik dalam menjaga jarak 1 meter.
\end{abstract}

Kata kunci : Pengetahuan, Perilaku, Covid-19 


\section{PENDAHULUAN}

Pandemi Covid-19 yang melanda Indonesia mampu melumpuhkan aktifitas normal yang dilakukan kalangan masyarakat di luar rumah. Coronavirus merupakan keluarga besar virus yang menyebabkan penyakit ringan sampai berat, seperti common cold atau pilek dan penyakit yang serius seperti MERS dan SARS (Kemendagri, 2020). Coronavirus Disease (Covid -19) adalah virus jenis baru yang belum pernah diidentifikasi sebelumnya pada manusia. Jumlah kasus Virus Corona terus bertambah dengan beberapa melaporkan kesembuhan, tapi tidak sedikit yang meninggal (Kemenkes,2020). Usaha penanganan dan pencegahan terus dilakukan demi melawan Covid -19. Tingginya kasus Covid-19 menjadi pertimbangan Pemerintah untuk membuat kebijakan Work From Home, School from Home, Lock Down dan Pembatasan Sosial Berskala Besar (PSBB).

Selain dampak kesehatan, pandemi Covid19 juga berdampak pada dunia pendidikan sekolah. Penutupan sementara lembaga pendidikan sebagai upaya menahan penyebaran pendemi covid-19 berdampak pada jutaan pelajar, tidak kecuali di Indonesia. Provinsi Bengkulu yang termasuk dalam Zona Merah Covid-19 dengan jumlah kasus sampai dengan bulan Oktober 2020 sebanyak 995 kasus, adapun kasus pada anak usia 6-18 tahun berjumlah 79 kasus. Di Kota Bengkulu sampai dengan tanggal 26 Oktober 2020, kasus Covid19 berjumlah 567 kasus (Tim e-Government Provinsi Bengkulu, 2020).

Usia sekolah merupakan usia yang cukup rentan terdampak Covid-19 karena sangat perlu pengawasan dari orang tua dan perlu pemahaman mengenai pencegahan Covid-19. Selama pandemi Covid-19 awal tahun 2020 melanda Indonesia khususnya Kota Bengkulu, sistem pembelajaran dilakukan secara daring sesuai Surat Edaran Walikota Bengkulu No. 420/ 9.19/ 1.D.DIK/ 2020 Tanggal 12 Juli 2020. Dimana materinya mempertegas bahwa sistem belajar mengajar ditingkat TK/ PAUD/ PKBM/ $\mathrm{SD} / \mathrm{MI} / \mathrm{SMP} / \mathrm{MTs}$ tetap menggunakan metode daring (Pemkot Bengkulu, 2020).

SDIT Rabbani Kota Bengkulu per tahun ajaran 2020/2021 merupakan sekolah yang pertama kali melakukan pembelajaran tatap muka dengan metode study club dan penerapan protokol kesehatan dengan status Kota Bengkulu zona orange. Keputusan membuka kembali sekolah tatap muka didapatkan berdasarkan kesepakatan bersama antara pihak sekolah dan orang tua murid tanpa ada paksaan dari pihak sekolah. Selama kegiatan pembelajaran tatap muka berlangsung, pihak sekolah telah mempersiapkan sarana dan prasaran penunjang dan kebijakan baru untuk mencegah penularan Covid-19 di lingkungan sekolah seperti menyediakan thermometer gun, face shield dan tempat cuci tangan. Beberapa kebijakan juga diterapkan seperti pengantaran dan penjemputan siswa hanya dilakukan di depan gerbang dan ada larangan masuk ke lingkungan sekolah bagi orang tua murid, pembagian kelompok belajar yang hanya diisi maksimal 12 siswa per kelas, jam belajar dipersingkat dan siswa hanya sekolah tiga hari dalam satu minggu.

Untuk mencegah dan memutus mata rantai penularan Covid-19 dilingkungan sekolah perlu pengetahuan yang baik terhadap pencegahan Covid-19 oleh seluruh siswa, guru dan warga sekolah lainnya serta perlu komitmen seluruh warga sekolah agar tetap disiplin dalam menjalankan protokol kesehatan selama pembelajaran tatap muka dilakukan. Pentingnya pengetahuan siswa terhadap pencegahan penularan Covid-19 sangat perlu diperhatikan agar tidak terjadi peningkatan kasus Covid-19 khususnya di lingkungan sekolah. Pengetahuan siswa tentang pencegahan Covid-19 dengan penerapan protokol kesehatan bisa dilakukan melalui sosialisasi dari pihak sekolah dan melalui media promosi kesehatan Tujuan penelitian ini yaitu untuk mengetahui tingkat pengetahuan siswa tentang pencegahan Covid-19 di SDIT Rabbani Kota Bengkulu. 


\section{METODE PENELITIAN}

Jenis penelitian yang digunakan adalah dengan desain cross sectional. Penelitian cross sectional hanya mengobservasi sekali saja dan pengukuran dilakukan terhadap variabel subjek pada saat penelitian (Notoadmodjo, 2012). Populasi dalam penelitian ini adalah seluruh siswa SDIT Rabbani Kota Bengkulu berjumlah 610 siswa (Kemdikbud, 2020). Pengambilan sampel pada penelitian ini menggunakan rumus penentuan sampel (Notoadmodjo, 2012) yaitu berjumlah 86 siswa. Data kuesioner yang terkumpul dianalisis menggunakan Software SPSS for Windows.

\section{HASIL DAN PEMBAHASAN}

HASIL

\section{Distribusi Frekuensi Pengetahuan Siswa}

Distribusi frekuensi pengetahuan siswa tentang penggunaan masker, mencuci tangan menggunakan sabun dan menjaga jarak 1 meter dapat dilihat pada tabel di bawah ini.

Tabel 1

Distribusi Frekuensi Pengetahuan Siswa

\begin{tabular}{lcc}
\hline \multicolumn{1}{c}{ Variabel } & N & $\%$ \\
\hline Pengetahuan: & & \\
\hline Menggunakan Masker & & \\
Tahu & 64 & 72,1 \\
Tidak Tahu & 24 & 27,9 \\
\hline Mencuci Tangan & & \\
Menggunakan Sabun & & \\
Tahu & 45 & 52,3 \\
Tidak Tahu & 41 & 47,7 \\
\hline Menjaga Jarak 1 meter & & \\
Tahu & 38 & 44,2 \\
Tidak Tahu & 48 & 55,8 \\
\hline
\end{tabular}

Hasil analisis menunjukkan bahwa sebagian besar siswa $(72,1 \%)$ mengetahui tentang penggunaan masker, sebagian besar siswa $(52,3 \%)$ mengatahui tentang mencuci tangan menggunaan sabun, sebagian kecil siswa $(44,2 \%)$ mengetahui tentang menjaga jarak 1 meter.

\section{Distribusi Frekuensi Perilaku Siswa}

Distribusi frekuensi perilaku siswa dalam penggunaan masker, mencuci tangan menggunakan sabun dan menjaga jarak 1 meter dapat dilihat pada tabel di bawah ini.

Tabel 2

Distribusi Frekuensi Perilaku Siswa

\begin{tabular}{lcc}
\hline \multicolumn{1}{c}{ Variabel } & N & $\%$ \\
\hline Pengetahuan: & & \\
\hline Menggunakan Masker & & \\
Baik & 49 & 57 \\
Kurang Baik & 37 & 43 \\
\hline Mencuci Tangan & & \\
Menggunakan Sabun & & \\
Baik & 34 & 39,5 \\
Kurang Baik & 52 & 60,5 \\
\hline Menjaga Jarak 1 meter & & \\
Baik & 27 & 31,4 \\
Kurang Baik & 59 & 68,6 \\
\hline
\end{tabular}

Hasil analisis menunjukkan bahwa sebagian besar siswa $(57 \%)$ berperilaku baik dalam menggunakan masker, sebagian kecil siswa $(39,5 \%)$ berperilaku baik dalam mencuci tangan menggunakan sabun dan sebagian kecil siswa $(31,4 \%)$ berperilaku baik dalam menjaga jarak 1 meter.

\section{PEMBAHASAN}

Dari hasil uji univariat didapatkan sebagian besar siswa mengetahui tentang penggunaan masker dan mencuci tangan menggunaan sabun, sebagian kecil siswa mengetahui tentang menjaga jarak 1 meter. Pengetahuan siswa tentang pencegahan covid19 ini diperoleh dari orang tua, sosialisasi dari pihak sekolah dan melalui media promosi kesehatan seperti spanduk dan baliho yang ada di sekolah. 
Pengetahuan merupakan hasil "tahu" dan ini terjadi setelah orang melakukan penginderaan terhadap suatu objek tertentu. Penginderaan ini terjadi melalui panca indra manusia. Pengetahuan atau kognitif merupakan domain yang sangat penting bagi terbentuknya tindakan seseorang. Perilaku yang didasari oleh pengetahuan akan lebih langgeng daripada perilaku yang tidak didasari oleh pengetahuan (Notoatmodjo, 2014).

Hasil penelitian yang dilakukan oleh Erlin, dkk (2020) mengenai tingkat pengetahuan siswa terhadap pencegahan virus corona di dapatkan hasil tingkat pengetahuan siswa tentang pencegahan virus corona masih sangat rendah, melihat hal tersebut, kurangnya pengetahuan anak mengenai cara pencegahan virus corona dapat berdampak pada meningkatnya jumlah kasus positif virus corona pada anak-anak. Hasil penelitian sukesih (2020), didapatkan hasil pada kuesioner pengetahuan paling tinggi di kategori baik sebanyak $228(51,35 \%)$. Hasil penelitian Muthiah (2020), didapatkan tingkat pengetahuan responden Kecamatan Tamalanrea mengenai pengetahuan umum Covid-19 pada kategori baik sebanyak $83,8 \%$, mengenai penggunaan masker bepengetahuan baik sebanyak $88,4 \%$, menjaga jarak berpengetahuan baik sebanyak $76,4 \%$ dan mencuci tangan berpengetahuan baik $97,3 \%$.

Dari hasil uji univariat didapatkan sebagian besar siswa berperilaku baik dalam menggunakan masker, sebagian kecil siswa berperilaku baik dalam mencuci tangan menggunakan sabun dan dalam menjaga jarak 1 meter. Perilaku siswa yang kurang baik dalam pencegahan covid-19 ini disebabkan kurangnya pengetahuan dan sikap dalam pencegahan covid-19. Perilaku pencegahan penularan virus corona terutama pada anak karena anak-anak masih suka bermain dengan teman-teman sesusianya sesuai dengan pertumbuhan dan perkembangan anak sehingga kebanyakan anak-anak masih belum memperhatikan pencegahan virus corona.

Perilaku merupakan hasil dari pada segala macam pengalaman serta interaksi manusia dengan lingkungannya yang terwujud dalam bentuk pengetahuan, sikap, dan tindakan. Perilaku merupakan respon atau reaksi seseoranng individu terhadap stimulus yang berasal dari luar maupun dari dalam diri (Sukarman, dkk, 2020).

Berdasarkan hasil penelitian Mujiburrahman, dkk (2020), menunjukkan bahwa perilaku responden dalam pencegahan COVID-19 sebagian besar dalam kategori cukup yaitu sebanyak 53 responden (51.0\%). Hasil penelitian Muthiah (2020), berdasarkan upaya dan tingkat pengetahuan menggunakan masker yang memiliki pengetahuan baik dan upaya yang baik terdapat sebanyak $78 \%$ responden. Berdasarkan pengetahuan baik tentang mencuci tangan dan memiliki upaya yang baik adalah $68,5 \%$ responden. Berdasarkan upaya menjaga jarak dan memiliki pengetahuan baik tentang menjaga jarak sebanyak $51,3 \%$.

Hasil penelitian lain dari Santoso dan Setyowati (2020), menunjukkan hasil bahwa tingkat pengetahuan masyarakat tentang tindakan pencegahan Covid-19 dalam katagori baik sebanyak 80 responden (88\%). Penelitian Gunawan, dkk (2021), didapatkan hasil penelitian pengetahuan responden mengenai COVID-19 $71,2 \%$ baik, sikap responden sebanyak $74,6 \%$ positif dan perilaku responden menunjukan $59,2 \%$ baik.

Hasil penelitian pada jurnal internasional yang dilakukan oleh Ernawati, dkk (2021) mengenai pengetahuan, sikap dan perilaku masyarakat dalam pencegahan penularan COVID-19 didapatkan hasil penelitian sepuluh artikel yang memenuhi kriteria inklusi, terdiri dari variabel sosiodemografi $100 \%$, pengetahuan $90 \%$, sikap $90 \%$, dan perilaku $80 \%$. Jumlah artikel dengan hasil penelitian signifikan pada variabel pengetahuan (mencakup aspek pengenalan penyakit, cara penularan, gejala umum, dan cara pencegahan) adalah $61,11 \%$ artikel. Jumlah artikel signifikan pada variabel sikap (meliputi isolasi diri, penggunaan masker, social distancing, COVID-19, dan pemerintah) adalah $35,54 \%$. Jumlah artikel substansial pada variabel perilaku preventif (mencakup cuci 
tangan, social distancing, hand sanitizer, penggunaan masker, dan isolasi diri) adalah $45 \%$.

\section{KESIMPULAN DAN SARAN}

Kesimpulan dari penelitian ini yaitu sebagian besar siswa mengetahui tentang penggunaan masker dan mencuci tangan menggunaan sabun, sebagian kecil siswa mengetahui tentang menjaga jarak 1 meter dan sebagian besar siswa berperilaku baik dalam menggunakan masker dan sebagian kecil siswa berperilaku baik dalam mencuci tangan menggunakan sabun dan dalam menjaga jarak 1 meter.

Disarankan kepada Pihak Sekolah untuk dapat meningkatkan pemberian informasi mengenai pencegahan covid-19 melalui $3 \mathrm{M}$ (memakai masker, mencuci tangan pakai sabun dan menjaga jarak 1 meter) kepada seluruh warga sekolah khususnya siswa melalui sosialisasi wali kelas, menempel media poster dimasing-masing kelas serta menambah jumlah spanduk yang berisikan informasi pencegahan covid-19 di lingkungan sekolah. Pemantauan harus terus dilakukan oleh guru dan wali kelas terhadap kedisiplinan siswa dalam menerapkan protokol covid-19 di lingkungan sekolah.

\section{DAFTAR PUSTAKA}

Erlin, Fitry, dan Putra, Ifon Driposwana. 2020. Peningkatan Pengetahuan Siswa Dalam Pencegahan Penularan Covid-19. Jurnal Masyarakat Mandiri (JMM). Vol. 4 No. 4. DOI: https://doi.org/10.31764/jmm.v4i4.2652

Ernawati, Kholis., Cantika, Istri Bela., Isaputri, Riska. 2021. Community knowledge, attitudes and behaviors in prevention of COVID-19 transmission: A systematic review. International Journal of Public Health Science (IJPHS). Vol. 10, No. 1, March 2021. DOI: http://doi.org/10.11591/ijphs.v10i1.206 $\underline{64}$
Gunawan, Susilawati., Sinsin, lis., dan Zani. 2021. Hubungan Antara Pengetahuan dan Sikap dengan Perilaku Pencegahan COVID19 Pada Peserta Seminar Online STIKes Raflesia 7 April 2020. : Indonesian Journal of Health Promotion and Behavior. 2021; 3 (1) ): 47-57 DOI: 10.47034/ppk.v3i1.4553

Kementerian Dalam Negeri. 2020. Pedoman Umum Menghadapi Pandemi Covid-19 bagi Pemerintah Daerah. Jakarta: Tim Kerja Kementerian Dalam Negeri.

Kementrian Kesehatan. 2020. Kesiapsiagaan Menghadapi Infeksi covid-19. Jakarta: Kementerian Kesehatan.

Kementerian Pendidikan dan Kebudayaan. 2020. Data Pokok SDIT Rabbani Kota Bengkulu. Jakarta: Kementerian Pendidikan dan Kebudayaan.

Mujiburrahman dan Muskhab Eko Riyadi. 2020. Pengetahuan Berhubungan dengan Peningkatan Perilaku Pencegahan COVID19 di Masyarakat. Jurnal Keperawatan Terpadu. Vol. 2, No.2. DOI: https://doi.org/10.32807/jkt.v2i2.85

Muthiah, Nadhifah Nurul. 2020. Tingkat Pengetahuan dan Upaya Masyarakat tentang Pencegahan Penularan COVID-19 di Kecamatan Tamalanrea, Kota Makassar. Skripsi. Makassar: Universitas Hasanudin. http://repository.unhas.ac.id/id/eprint/1860/2/ C011171531_skripsi\%201-2.pdf

Notoatmodjo, Soekidjo 2012. Metode Penelitian Kesehatan. Jakarta : Rineka Cipta.

Notoatmodjo, Soekidjo. 2014. IImu Perilaku Kesehatan. Jakarta: Rineka Cipta.

Pemerintah Kota Bengkulu. 2020. Surat Edaran Walikota Bengkulu No. 420/ 9.19/ 1.D.DIKI 
2020 Tanggal 12 Juli 2020. Bengkulu: Pemerintah Kota Bengkulu.

Santoso, Puguh dan Setyowati, Novita. 2020. Hubungan Tingkat Pengetahuan Masyarakat Dengan Tindakan Preventif Covid-19. Jurnal Keperawatan Jiwa Volume $8 \quad$ No 4, November 2020. DOI: https://doi.org/10.26714/jkj.8.4.2020.36 $\underline{5-370}$

Sukarman. 2020. Perilaku Organisasi. Medan: Yayasan Kita Menulis.

Sukesih dan Usman. 2020. Pengetahuan dan Sikap Mahasiswa Kesehatan tentang Pencegahan Covid-19 Di Indonesia. Jurnal Ilmu Keperawatan dan Kebidanan. Vol 11, No 2.2 DOI: http://dx.doi.org/10.26751/jikk.v11i2.835

Tim e-Government Provinsi Bengkulu. 2020. Perkembangan Kasus Covid-19 Provinsi Bengkulu. Bengkulu: Tim e-Government Provinsi Bengkulu. 